\title{
MANAJEMEN KEPEMIMPINAN KEPALA SEKOLAH PEREMPUAN: ANALISIS MODEL CIPP
}

\author{
Widyatmike Gede Mulawarman ${ }^{1}$, Ambar Putri Srihandari ${ }^{2}$ \\ FKIP Universitas Mulawarman ${ }^{1,}$ SMAN 1 Kutai Barat ${ }^{2}$ \\ e-mail: widyatmike@ fkip.unmul.ac.id, arinanyeq9@gmail.com ${ }^{2}$
}

Received: 02 Oktober 2020; Revised: 21 November 2020; Accepted: 28 Desember 2020 DOI: http://dx.doi.org/10.37905/aksara.7.1.1-14.2021

\begin{abstract}
Abstrak
Dominasi laki-laki masih bertahan pada posisi manajemen sekolah meskipun fenomena proporsi perempuan mencapai peran kepemimpinan terus meningkat..Tujuan penelitian ini adalah mendeskripsikan manajemen kepemimpinan perempuan dengan mengamati perilaku kepemimpinan perempuan di sekolah. Jenis penelitian kualitatif dengan menerapkan observasi, wawancara dan dokumentasi saat penyediaan data. Hasil penelitian menunjukkan (1) Perencanaan peningkatan mutu pendidikan berdasarkan visi, misi, yang disusun sesuai arahan Kepala Dinas Pendidikan Kabupaten Kutai barat; (2) Pengorganisasian lembaga dilaksanakan secara tanggung jawab , menciptakan iklim sekolah yang kondusif. (3) Sistem monitoring aktivitas guru, hasil belajar siswa melalui supervisi akademik ; (4) Sistem evaluasi aktivitas SMPN 4 melibatkan orang tua secara mufakat.
\end{abstract}

Kata Kunci: Manajemen , Kepemimpinan perempuan , dan Model CIPP

\section{Abstract}

The dominance of men still remains in school management positions even though the phenomenon of the proportion of women achieving leadership roles continues to increase. The aim of this study is to describe women's leadership management by observing women's leadership behavior in schools. This type of qualitative research applies observation, interviews and documentation when providing data. The results showed (1) Planning to improve the quality of education based on the vision, mission, which is arranged accordingly directions from the Head of the West Kutai Regency Education Office; (2) Organizing institutions is carried out responsibly, creating a conducive school climate. (3) Monitoring system for teacher activities, student learning outcomes through academic supervision; (4) The SMPN 4 activity evaluation system involves parents by consensus.

Keywords: Management, women's leadership, and the CIPP Model

\section{Pendahuluan}

Keberhasilan suatu organisasi atau institusi ditentukan oleh kehadiran seorang pemimpin (Wirawan, 2013). Pemimpin adalah seseorang memiliki kemampuan lebih dalam mengatur dan mengarahkan orang lain serta mampu menjadi representatif dari kebutuhan organisasi demi mencapai tujuannya. Setidaknya ada empat alasan mengapa seorang pemimpin diperlukan, yaitu (1) karena banyak orang memerlukan figur pemimpin, (2) dalam beberapa situasi, seorang pemipin perlu tampil mewakili kelompoknya, (3) sebagai tempat 
pengambilan resiko bila terjadi tekanan terhadap kelompoknya, dan (4) sebagai tempat untuk meletakkan kekuasaan (Djafri, 2017). Setiap pemimpin hendaknya memiliki gaya kepemimpinan tersendiri menjadi karakteristik setiap pemimpin organisasi pendidikan atau sekolah, dalam hal ini kepala sekolah.

Efektivitas seorang pemimpin ditentukan oleh kepiawaiannya mempengaruhi dan mengarahkan para anggota sekolah. Pemimpin dapat mempengaruhi semangat dan kegairahan kerja, keamanan, kualitas kehidupan kerja dan juga tingkat prestasi suatu organisasi pendidikan (Sutanto \& Stiawan, 2000). Pemimpin juga memainkan peranan penting dalam membantu kelompok, individu untuk mencapai tujuan. Pemimpin adalah seorang pribadi yang memiliki kecakapan dan kelebihan, khususnya kecakapan/kelebihan di satu bidang sehingga dia mampu mempengaruhi orang lain untuk bersama-sama melakukan aktivitas-aktivitas tertentu demi pencapaian satu atau beberapa tujuan . Kepemimpinan yang diyakini salah satu faktor penting yang mempengaruhi prestasi bawahan. Salah satu faktor penting yang mempengaruhi keberhasilan proses kepemimpinan adalah perilaku pemimpin yang bersangkutan atau gaya pemimpin.

Gaya kepemimpinan diartikan sebagai perilaku atau cara yang dipilih dan dipergunakan pemimpin dalam mempengaruhi pikiran, perasaan, sikap, dan perilaku organisasinya (Apriani, 2011)). Gaya kepemimpinan juga diartikan sebagai cara seorang pemimpin mempengaruhi perilaku bawahan, agar mau bekerjasama dan bekerja secara produktif untuk mencapai tujuan organisasi (Wibowo, Si, \& Saputra, 2017).

Beberapa hasil penelitian yang relevan dengan permasalahan gaya kepemimpinan di sekolah yang mendeskripsikan tentang efektif adalah sekolah yang memiliki kepemimpinan yang kuat, memiliki harapan yang tinggi bagi siswa dan guru, lingkungan sekolah yang kondusif, kepemimpinan yang menekankan pada instructional leader, kemajuan siswa seiring monitoring dan adanya dukungan dan pelibatan orang tua secara aktif. Hal serupa juga dikemukakan (Gibson, Ivancevich, \& Donnelly, 1996) bahwa sekolah efektif adalah sekolah yang memiliki kualitas mutu yang dapat dilihat input, proses output. Aspek input berkaitan dengan berlangsungnya proses yang mencakup kepala sekolah dan perangkat pendidik. Sementara proses mencakup kejadian berubahnya sesuatu menjadi sesuatu yang lain, dan output merupakan kinerja sekolah baik itu mengenai kualitas, efisiensi, inovasi serta termasuk prestasi siswa akademik dan non akademik (Winardi, Nurkolis, \& Yuliejantiningsih, 2017). Upaya mewujudkan sekolah yang efektif sangat bergantung pada gaya kepemimpinan kepala sekolah itu sendiri sehingga terciptalah sekolah yang efektif yang dengan sendirinya akan menciptakan lingkungan iklim sekolah yang kondusif, dengan tolak ukurnya adalah hasil belajar siswa serta kualitas mutu pembelajaran dari sekolah itu sendiri

Pergeseran partisipasi perempuan yang pindah ke posisi kepemimpinan dalam bisnis dan manajemen ditandai dengan jumlah perempuan meningkat sebagai pemimpin dalam suatu lembaga sekolah. (Acker, 1995); (Carli \& Eagly, 1999). Dominasi laki-laki sebagai pemimpin dalam sebuah organisasi atau institusi relatif semakin meningkat dan memang masih begitu kuat (C L Hoyt \& Simon, 2016). Namun realitasnya, perempuanpun mempunyai potensi yang tidak kalah penting dengan laki-laki dalam hal memimpin (Acker, 1995). Kepemimpinan, tidak mungkin dapat terlepas dari individu yang berperan sebagai pemimpin itu sendiri. Banyak yang menghubungkan antara kemampuan individu dalam memimpin dengan aspek biologis yang melekat pada diri sang pemimpin yaitu berdasarkan pada perbedaan jenis kelamin laki-laki dan perempuan (Coder \& Spiller, 2013) . Kondisi ini kemudian menyebabkan munculnya istilah 
kesenjangan gender (jenis kelamin laki-laki dan perempuan) yang kemudian memosisikan perempuan pada kondisi yang tidak menguntungkan, walaupun perempuan adalah sumber daya manusia yang bahkan di seluruh dunia jumlahnya jauh lebih besar daripada laki-laki (Crystal L Hoyt \& Burnette, 2013).

Terkait dengan kepemimpinan perempuan, dalam sejarah dunia telah muncul 68 orang perempuan sebagai presiden dan perdana menteri di berbagai negara di seluruh dunia peran dan kepemimpinan perempuan sangat menetukan perkembangan dan kemakmuran suatu negara. Negara-negara makmur jumlah perempuan yang bekerja lebih banyak dari pada negara-negara miskin. Di negara-negara tersebut wanita juga memegang peranan besar dalam pemerintahan bisnis dan masyarakat (Crystal L Hoyt \& Burnette, 2013). Namun sejumlah orang berpendapat bahwa perempuan kurang cocok untuk menduduki posisi kepemimpinan, bahkan dalam masyarakat konvensional perempuan masih ditolak untuk menjadi pemimpin. Dalam Bidang ketenagakerjaan, serta undang-undang ketenagakerjaan hak-hak perempuan sama dengan laki-laki, akan tetapi sebagian manajer masih menganggap tetap pada perbedaan gender dalam ketenagakerjaan. Mereka menganggap kinerja perempuan tidak sama dengan kinerja laki-laki .

Persoalan sosok perempuan menarik untuk diteliti karena peranannya yang begitu menonjol dalam urusan melayani dan mendidik, juga memiliki spesifikasi pribadi yang lembut, tidak berlebihan dalam penampilan sehari-hari tetapi mampu menyelesaikan banyak masalah, seta seringkali dapat memberikan kontribusi positif terhadap berbagai bidang kehidupan. Di zaman kesetaraan dan keadilan gender (KKG) ini sudah tidak lagi relevan diskriminasi terhadap perempuan karena pembagian kerja secara seksual telah terbukti perempuan lebih dominan sehingga dalam pembagian kerja tidak perlu lagi ada pihak yang diuntungkan tapi lebih pada faktor kerelaan dan bekerja sama demi keutuhan, keharmonisan dan kerjasama yang saling menguntungkan menuju suasana kerja yang menyenangkan.

Berdasarkan Peraturan Menteri Pendidikan Nasional Nomor 13 Tahun 2007 tentang standar kepala sekolah melengkapi peraturan sebelumnya yaitu UU sisdikanas tahun 2003 terdapat kualifikasi umum dan kualifikasi khusus yang harus dimiliki kepala sekolah maka siapa saja bisa mencalonkan diri sebagai kepala sekolah dan baik laki-laki maupun perempuan yang mampu untuk memenuhi standar kerja, akademis serta pengalaman yang dimiliki.

Demikian pula dalam UU No. 20 Tahun 2003 tentang Sistem Pendidikan Nasional dan peraturan lainnya diatur bahwa promosi jabatan dalam bidang kepemimpinan sekolah didasarkan atas prestasi kerja bukan atas karakter khusus perempuan atau laki-laki. Namun secara faktual berdasarkan analisis gender, khususnya di Provinsi Kalimantan Timur masih ditemukan kendala budaya dan struktural yang membuat perempuan menghadapi kesulitan untuk menduduki jabatan kepala sekolah. Ada banyak rambu-rambu yang diberikan kepada perempuan agar tidak melakukan aktivitas tertentu terutama di sektor publik, karena merupakan tugas laki-laki (Alice Hendrickson Eagly, Eagly, \& Carli, 2007).

Tidak bebasnya perempuan bekerja di sektor publik misalnya di sekolah, membuat kemampuannya untuk merebut posisi kepala sekolah semakin kecil, padahal diketahui jumlah guru perempuan di SMP Negeri dan Swasta Kabupaten Kutai Barat cukup besar. Menurut data Kantor Dinas Pendidikan di Kabupaten Kutai Barat (2019) jumlah guru perempuan 168 orang dan laki-laki 143 orang. Sekalipun jumlah guru perempuan cukup besar, mereka kurang dapat mengembangkan kariernya sampai ke jenjang kepala sekolah. Diketahui, hanya ada 10 orang perempuan sebagai kepala sekolah lanjutan pertama negeri dan 33 orang laki-laki, Demikian pula pada SMP Swasta hanya ada 2 orang perempuan sebagai kepala sekolah 
dan 16 orang laki-laki. Ketimpangan tersebut berarti pula ketimpangan dalam akses, partisipasi dan kesempatan, maupun perlakuan yang diperoleh guru perempuan untuk mencapai posisi sebagai kepala sekolah.

Penyebab rendahnyanya partisipasi perempuan sebagai kepala Sekolah SMP di Kabupaten Kutai Barat antara lain karena adanya persepsi yang cenderung menjadi citra baku yang diatur oleh budaya atau juga sebagai gender (Carli \& Eagly, 2001). Pandangan tentang norma-norma yang mengatur hubungan perempuan dan laki-laki yang ada dalam masyarakat berlaku pula dalam bidang pendidikan, terutama dalam penentuan dan seleksi kepala sekolah yang masih mengacu pada model laki-laki.

\section{Metode}

Jenis penelitian ini adalah penelitian deskriptif kualitatif yang berlandaskan pada Filsafat Postpositivisme yaitu pandangan yang menngamati kondisi objek yang alamiah dan menempatkan peneliti sebagai instrumen kunci. (Sugiyono, 2013). Tujuan penelitian ini untuk memperoleh gambaran tentang keefektifan kepemimpinan perempuan sebagai kepala sekolah berdasarkan perspektif gender. Dari tujuan tersebut jelaslah bahwa yang menjadi substansi penelitiannya adalah perilaku kepemimpinan perempuan sebagai kepala sekolah, sehingga datanya bersifat kualitatif dan latarnya alami.

Teknik pengumpulan data dalam penelitian ini adalah metode observasi, dokumentasi, dan wawancara. Beberapa informasi yang diperoleh dari hasil observasi adalah ruang (tempat), pelaku, kegiatan, objek, perbuatan, kejadian atau peristiwa, waktu, dan perasaan. Alasan peneliti melakukan observasi adalah untuk menyajikan gambaran realistik perilaku atau kejadian untuk menjawab pertanyaan, untuk membantu mengerti perilaku manusia, dan untuk evaluasi yaitu melakukan pengukuran terhadap aspek tertentu, melakukan umpan balik terhadap pengukuran tersebut. Data dokumentasi mencakup: visi dan misi sekolah, usulan program, program kerja sekolah dan kepala sekolah, kebijakan-kebijakan, laporan tahunan sekolah, instrumen supervisi kepala sekolah, daftar-daftar, statistik, notulen rapat komite, masa kerja, tingkat pendidikan, jenis kelamin, suku, agama kepala sekolah dan guru serta staf tata usaha, biografí kepala sekolah, daftar jumlah siswa, satuan pelajaran, jurnal harian mengajar, analisis hasil ulangan, rekap keadaan proses belajar mengajar, format administrasi, piagam penghargaan, daftar sarana dan prasarana. Isu-isu pokok dalam wawancara antara lain mencakup: perempuan dan peran gendernya, kompetensi perempuan sebagai kepala sekolah, visi dan misi sekolah, program kerja, fungsi dan tugas sebagai kepala sekolah, gaya kepemimpinan kepala sekolah, proses administrasi dan substansi administrasi, supervisi, hubungan kepala sekolah dan staf, hubungan kepala sekolah dengan orang tuamasyarakat, pembinaan siswa, guru Bimbingan Konseling. Semua informasi yang diperoleh melalui wawancara mendalam baik menggunakan alat perekam maupun manual, kemudian ditranskripsikan (dialihkan ke dalam bentuk tertulis).

Penelitian ini dirancang dengan menggunakan Model evaluasi yang digunakan dalam memonitoring program ini adalah model evaluasi Context-Input-Process-Product (CIPP) (Stufflebeam, 2007). Tujuannya adalah untuk mengumpulkan informasi yang akurat dalam efektifitas kepemimpinan perempuan sebagai kepala sekolah guna memperbaiki dan meningkatkan kualitas penyelenggaraan program SMP Negeri 4 Sendawar. 


\section{Hasil dan Pembahasan \\ Hasil}

Sekolah SMPN 4 di Sendawar merupakan salah satu sekolah SMP negeri yang ada di Kabupaten Kutai Barat. Berikut diinformasikan sejarah kepemimpinan kepala sekolah sejak awal dibangun hingga sekarang. Bila dicermati partisipasi perempuan dalam kepemimpinan Kepala Sekolah di SMP Negeri 4 baru pada tahun 2014 tampak partisipasi perempuan. Berikut tabel nama kepala sekolah yang pernah menududuki jabatan kepala sekolah:

Tabel 1 Nama-Nama Kepala Sekolah yang Pernah Menjabat di SMP Negeri 4 Sendawar

\begin{tabular}{clll}
\hline No & \multicolumn{1}{c}{ Nama } & \multicolumn{1}{c}{ Periode Tugas } & Keterangan \\
\hline 1. & Tongkak & Sebelum 2009/2010 & Kepala Sekolah \\
2. & Syahran, S.Pd & Mulai 2010 s.d. 2014 & Kepala Sekolah \\
3. & Inoq Usat, S.Pd & Mulai 2014 - sampai sekarang & Kepala Sekolah \\
\hline
\end{tabular}

Berdasarkan tabel 1, sejak tahun 2009 hingga 2014, SMPN IV Sendawar dipimpin kepala sekolah laki-laki, namun sejak 2014 hingga sekarang pimpinan Sekolah SMPN IV dipimpin kepala sekolah perempuan. Selama kepemimpinan Ibu Inoq Usat, S.Pd. menunjukan perubahan pesat dengan ditandai adanya peningkatan siswa yang diterima di SMPN IV Sendawar. Berikut ini ialah penerimaan siswa pada 3 tahun terakhir yang dapat dicermati pada tabel 2 berikut ini.

Tabel 2 Data Siswa Penerimaan Siswa Baru 3 Tahun Terakhir

\begin{tabular}{cccccccccc}
\hline $\begin{array}{c}\text { Th. } \\
\text { Pelajaran }\end{array}$ & $\begin{array}{c}\text { Pendaftar } \\
\text { (CIn Siswa } \\
\text { Baru) }\end{array}$ & \multicolumn{2}{c}{ Kelas VII } & \multicolumn{2}{c}{ Kelas VIII } & \multicolumn{2}{c}{ Kelas IX } & \multicolumn{2}{c}{ Jumlah } \\
Siswa & $\begin{array}{c}\text { Jumlah } \\
\text { Rombel }\end{array}$ & $\begin{array}{c}\text { Jml } \\
\text { Siswa }\end{array}$ & $\begin{array}{c}\text { Jumlah } \\
\text { Rombel }\end{array}$ & $\begin{array}{c}\text { Jml } \\
\text { Siswa }\end{array}$ & $\begin{array}{c}\text { Jumlah } \\
\text { Rombel }\end{array}$ & Siswa & Rombel \\
\hline $2016 / 2017$ & 42 & 42 & 2 & 45 & 2 & 43 & 2 & 130 & 6 \\
$2017 / 2018$ & 60 & 60 & 3 & 55 & 2 & 45 & 2 & 160 & 7 \\
$2018 / 2019$ & 48 & 48 & 2 & 60 & 3 & 44 & 2 & 152 & 7 \\
\hline
\end{tabular}

Berdasarkan tabel 2 data siswa penerimaan siswa baru 3 tahun terakhir tampak bahwa jumlah siswa setiap tahunnya mengalami peningkatan. Hal ini juga yang membuat ibu kepala sekolah untuk berusaha mewujudkan sekolahnya sesuai dengan visi dan misi sekolah. Keberhasilan Ibu Kepala Sekolah didukung kerjasama yang baik dengan perangkat sekolah. Berikut ini data perangkat sekolah yang ada di SMPN IV Sendawar.

Data perangkat sekolah ini ialah berisi data nama waka kurikulum berdasarkan jenis kelamin beserta latar belakang pendidikannya. Bila mencermati tabel 3 ternyata yang mendampingi dan membantu keberlangsungan proses pengembangan sekolah SMPN IV Sendawar adalah laki-laki. Dapat dilihat pada tabel 3 sebagai berikut ini: 
Tabel 3 Data Perangkat Sekolah

\begin{tabular}{|c|l|l|c|c|c|c|c|}
\hline \multirow{2}{*}{$\begin{array}{c}\text { N } \\
\text { o }\end{array}$} & \multicolumn{1}{|c|}{ Jabatan } & \multicolumn{1}{|c|}{ Nama } & \multicolumn{2}{|c|}{$\begin{array}{c}\text { Jenis } \\
\text { Kela-min }\end{array}$} & $\begin{array}{c}\text { Usi } \\
\text { a }\end{array}$ & $\begin{array}{c}\text { Pend } \\
\text { Akhir }\end{array}$ & $\begin{array}{c}\text { Mas } \\
\text { Kerj } \\
\text { Kerj }\end{array}$ \\
\hline 1. & Waka kurikulum & Supardi, S.Pd & L & & & S1 & \\
\hline 2. & Waka Kesiswaan & $\begin{array}{l}\text { Fachrujiansyah } \\
\text { B, S.Pdi }\end{array}$ & L & & & S1 & \\
\hline 3. & Waka Humas & $\begin{array}{l}\text { Evodius } \\
\text { Savang G, S.Pd }\end{array}$ & L & & & S1 & \\
\hline 4. & Waka Sarpras & Supardi, S.Pd & L & & & S1 & \\
\hline 5. & $\begin{array}{l}\text { Waka Menejemen } \\
\text { Mutu }\end{array}$ & & & & & & \\
\hline
\end{tabular}

Selain perangkat sekolah yang memiliki kualifikasi pendidikan yang baik, semua berkualifikasi S1, di SMPN IV Sendawar dikuatkan juga dengan guru-guru yang mengajar juga berkualifikasi S1. Berikut data guru SMPN IV Sendawar berdasarkan kualifikasi pendidikan, Status, jenis kelamin dapat dilihat pada tabel 4 sebagai berikut:

Tabel 4 Jumlah Guru Berdasarkan Kualifikasi Pendidikan, Status, dan Jenis Kelamin

\begin{tabular}{|c|c|c|c|c|c|c|}
\hline \multirow{3}{*}{ No. } & \multirow{3}{*}{$\begin{array}{c}\text { Tingkat } \\
\text { Pendidikan }\end{array}$} & \multicolumn{4}{|c|}{ Jumlah dan Status Guru } & \multirow{3}{*}{ Jumlah } \\
\hline & & \multicolumn{2}{|c|}{ GT/PNS } & \multicolumn{2}{|c|}{$\begin{array}{c}\text { GTT/Guru } \\
\text { Bantu }\end{array}$} & \\
\hline & & $\mathbf{L}$ & $\mathbf{P}$ & $\mathbf{L}$ & $\mathbf{P}$ & \\
\hline 1. & $\mathrm{~S} 2$ & & & & & \\
\hline 2. & S1 & 6 & 10 & 1 & & 17 \\
\hline 3. & D-4 & & & & & \\
\hline 4. & D3/Sarmud & & & & 1 & 1 \\
\hline 5. & D2 & & & & & \\
\hline 6. & D1 & & & & & \\
\hline 7. & $\leq$ SMA/sederajat & & & & & \\
\hline . & Jumlah & & & & & 18 \\
\hline
\end{tabular}

Hasil Pengamatan Kepala Sekolah, Guru dan Orang Tua Siswa :

\section{Kesamaan}

Untuk mencapai tujuan bersama mewujudkan visi misi sekolah kepala sekolah sebagai penanggung jawab harus berusaha untuk merancang sebuah visi dan misi kemudian mensosialisasikannya terhadap guru-guru dan seluruh warga sekolah selain itu kesamaanturut merumuskan visi misi serta tujuan Mencipatakan lingkungan sekolah yang kondusif, serta bekerja sama untuk memantau Aktivitas belajar siswa dan turut berpartisipasi dalam kegiatan sekolah. Sehingga tujuan sekolah dapat dicapai secara bersama-sama.

\section{Kemiripan}

Berdasarkan hasil pengumpulan data yang telah dilakukan dapat diketahui bahwa terdapat kemiripan hasil terhadap data yang dikumpulkan mengenai efektifitas kepemimpinan perempuan sebagai kepala sekolah. Adapun kemiripan data antara kepala 
sekolah dengan guru antara lain yakni Menjalin kordinasi dengan guru sehingga penyampaian visi misi dan hal-hal lainnya yang berkaitan dengan pembelajaran, serta menjalin komunikasi, dan tentunya Partisipasi antar kepala sekolah dan guru. Sedangkan kemiripan antara guru dengan orang tua siswa ialah mengikuti sosialiasai dari kepala sekolah mengenai visi dan misi serta tujuan, dan kemudian mengikuti kegiatan sekolah, serta memantau aktivitas siswa beserta anak didiknya. Kemiripan anatara kepala sekolah dengan orang tua siswa yakni tetap menjalin komunikasi, serta turut berpartisispasi dalam kegiatan sekolah dan memantau hasil belajar siswa.

3. Perbedaan

Tugas dari seorang kepala sekolah ialah mampu mengkoordinir guru dan seluruh anggota sekolah hingga mampu mewujudkan sekolah yang ingin diwujudkan.Adapun perbedaan antar kepala sekolah dengan guru serta peran orang tua siswa. Adapun peran kepala sekolah yakni memberikan pemahaman tentang visi misi dan tujuan, memberikan arahan mengenai capain suasana sekolah kondusif, memberikan pemahaman tentang supervisi, mengadakan musyawarah dengan orang tua dan masyarakat, sedangkan peran guru yakni menerima arahan arahan dari kepala sekolah, menerima arahan kepala sekolah mengenai sekolah yang kondusif, melaksanakan supervisi, dan turut membantu memantau prestasi siswa, membantu kepala sekolah dalam pelibatan orang tua dalam kegiatan sekolah.

Tabel 5

\section{Indikator-Indikator Evaluasi Efektivitas Kepemimpinan Perempuan pada SMP 4 Negeri Sendawar}

\begin{tabular}{|c|c|c|c|}
\hline Context & Input & Process & Output \\
\hline $\begin{array}{l}\text { 1. Efektivitas kepala sekolah } \\
\text { dalam merumuskan visi, } \\
\text { misi dan tujuan jangka } \\
\text { pendek dan jangka panjang }\end{array}$ & \begin{tabular}{|ll} 
1. & Guru dan Tenaga \\
Administrasi \\
2. & Orang Tua Siswa \\
3. & Siswa \\
4. & Program Kegiatan
\end{tabular} & $\begin{array}{l}\text { 1. Pelaksanaan Misi guna } \\
\text { pencapaian Visi dan } \\
\text { tujuan }\end{array}$ & $\begin{array}{l}\text { 1. Penerapan serta } \\
\text { Pencapaian Visi dan } \\
\text { tujuan }\end{array}$ \\
\hline $\begin{array}{l}\text { 2. Efekvitas kepala sekolah } \\
\text { dalam memimpin dengan } \\
\text { tanggung jawab dan } \\
\text { menciptakan iklim sekolah } \\
\text { yang kondusif }\end{array}$ & $\begin{array}{ll}\text { 1. } & \text { Guru dan Tenaga } \\
\text { 2. } & \text { Administrasi } \\
\text { 3. } & \text { Siswa Tua Siswa } \\
\text { 4. } & \text { Sarana belajar } \\
\text { 5. } & \text { Bahan Ajar } \\
\text { 6. } & \text { Program Kegiatan }\end{array}$ & $\begin{array}{l}\text { 1. Pelaksanaan kegiatan } \\
\text { belajar mengajar }\end{array}$ & $\begin{array}{l}\text { 1. Suasana sekolah yang } \\
\text { kondusif }\end{array}$ \\
\hline $\begin{array}{l}\text { 3. Efektivitas kepala sekolah } \\
\text { dalam memonitoring guru } \\
\text { dan siswa }\end{array}$ & $\begin{array}{ll}\text { 1. } & \text { Guru } \\
\text { 2. } & \text { Siswa } \\
\text { 3. } & \text { Sarana belajar } \\
\text { 4. } & \text { Bahan Ajar }\end{array}$ & $\begin{array}{l}\text { 1. Pelaksanaan supervisi } \\
\text { guru dan monitoring } \\
\text { hasil belajar siswa }\end{array}$ & $\begin{array}{l}\text { 1. Hasil belajar siswa dan } \\
\text { kinerja guru }\end{array}$ \\
\hline $\begin{array}{l}\text { 4. Efektivitas kepala sekolah } \\
\text { dalam melibatkan orang tua } \\
\text { dan masyarakat sekitar } \\
\text { dalam kegiatan sekolah }\end{array}$ & $\begin{array}{ll}\text { 1. } & \text { Guru dan Tenaga } \\
\text { 2. } & \text { Administrasi } \\
\text { 2. } & \text { Orang Tua Siswa } \\
\text { 3. } & \text { Siswa } \\
\text { 4. } & \text { Program Kegiatan }\end{array}$ & $\begin{array}{l}\text { 1. Pelaksanaan rapat komite } \\
\text { sekolah dan event-event } \\
\text { kegiatan yang diadakan } \\
\text { sekolah yang melibatkan } \\
\text { orang tua siswa dan } \\
\text { masyarakat sekitar }\end{array}$ & $\begin{array}{l}\text { 1. Hubungan baik } \\
\text { antara sekolah dengan } \\
\text { orang tua siswa }\end{array}$ \\
\hline
\end{tabular}


Volume : 07

Nomor : 01

Bulan : Januari

Tahun : 2021

http://ejurnal.pps.ung.ac.id/index.php/AKSARA/index

Tabel 6

Kriteria Evaluasi Efektivitas Kepemimpinan Perempuan Kepala Sekolah Berdasarkan Berperspektif Gender

\begin{tabular}{|c|c|c|c|}
\hline No. & Komponen Evaluasi & Aspek Evaluasi & $\begin{array}{c}\text { Standar } \\
\text { Keberhasilan }\end{array}$ \\
\hline 1. & $\begin{array}{lr}\text { Efektifitas } & \text { kepala } \\
\text { sekolah } & \text { dalam } \\
\text { merumuskan visi, misi } \\
\text { dan tujuan jangka } \\
\text { pendek dan jangka } \\
\text { panjang }\end{array}$ & $\begin{array}{l}\text { 1. Menyusun visi dan } \\
\text { misi } \\
\text { 2. Menyusun tujuan } \\
\text { jangka panjang dan } \\
\text { menengah serta } \\
\text { tujuan jangka } \\
\text { panjang }\end{array}$ & $\begin{array}{l}\text { 1. Pencapaian Visi } \\
\text { dan tujuan } \\
\text { sekolah }\end{array}$ \\
\hline 2. & $\begin{array}{lr}\text { Efekvitas } & \text { kepala } \\
\text { sekolah dalam } \\
\text { memimpin dengan } \\
\text { tanggung jawab dan } \\
\text { menciptakan iklim } \\
\text { sekolah yang kondusif }\end{array}$ & $\begin{array}{l}\text { 1. Mengevaluasi } \\
\text { kepemimpinan } \\
\text { kepala sekolah } \\
\text { 2. Suasana serta } \\
\text { keadaan lingkungan } \\
\text { sekolah } \\
\text { 3. Komunikasi antara } \\
\text { anggota sekolah } \\
\end{array}$ & $\begin{array}{l}\text { 1. Kepemimpinan } \\
\text { kepala sekolah } \\
\text { dengan tanggung } \\
\text { jawab } \\
\text { 2. Keadaan } \\
\text { lingkungan } \\
\text { sekolah yang } \\
\text { kondusif } \\
\end{array}$ \\
\hline 3. & $\begin{array}{lr}\text { Efektifitas } & \text { kepala } \\
\text { sekolah } & \text { dalam } \\
\text { memonitoring guru dan } \\
\text { siswa }\end{array}$ & $\begin{array}{l}\text { 1. } \begin{array}{l}\text { Pelaksanaan } \\
\text { program } \\
\text { guru }\end{array} \\
\text { 2. } \begin{array}{l}\text { Kegiatan } \\
\text { mengajar }\end{array} \\
\begin{array}{l}\text { dikelas } \\
\text { dikisi }\end{array} \\
\end{array}$ & $\begin{array}{l}\text { 1. Peningkatan } \\
\text { kinerja guru } \\
\text { 2. Peningkatan hasil } \\
\text { belajar siswa } \\
\text { maupun } \\
\text { keikutsertaan } \\
\text { siswa dalam } \\
\text { lomba-lomba }\end{array}$ \\
\hline 4. & $\begin{array}{l}\text { Efektifitas kepala } \\
\text { sekolah dalam } \\
\text { melibatkan orang tua } \\
\text { dan masyarakat sekitar } \\
\text { dalam kegiatan sekolah }\end{array}$ & 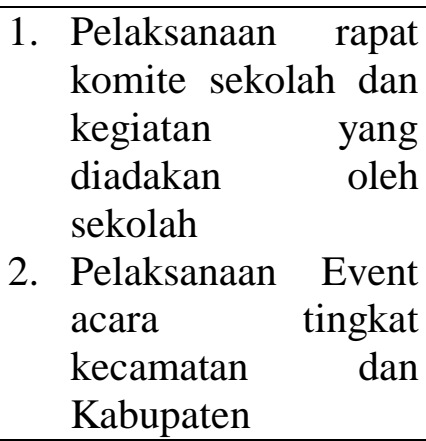 & $\begin{array}{l}\text { 1. Keikutsertaan/ } \\
\text { partisipasi orang } \\
\text { tua murid dan } \\
\text { masyarakat } \\
\text { sekitar dalam } \\
\text { kegiatan sekolah }\end{array}$ \\
\hline
\end{tabular}

\section{Pembahasan}

Analisis CIPP Kepemimpinan Kepala Sekolah Perempuan

a. Efektifitas kepala sekolah dalam merumuskan visi, misi sekolah serta program jangka kerja panjang dan jangka pendek sekolah.

Evaluasi konteks efektifitas kepala sekolah dalam merumuskan visi, misi sekolah serta program kerja jangka panjang dan jangka pendek sekolah dengan mencermati dokumen Visi dan Misi Sekolah SMPN IV Kabupaten Kutai Barat . 
Sekolah dan kepala sekolah memiliki visi dan misi yang akan dicapai dalam kurun waktu tertentu. Menurut kepala sekolah perumusan visi dan misi disesuaikan arahan dari Kepala Dinas Pendidikan Kabupaten Kutai Barat dan berdasarkan acuan dari Kementerian Pendidikan dan Kebudayaan. Pedoman penyusunan visi dan misi diperoleh kepala sekolah melalui pelatihan, penataran, dan diskusidiskusi. Selanjutnya kepala sekolah meneruskan kepada guru-gurunya dengan tujuan agar mereka juga mengetahuinya.Selanjutnya mencari referensi dan membaca buku panduan serta mendeskripsikan sekolah masa depan yang ingin diwujudkan, serta layanan-layanan apa saja yang diberikan dan langkah-langkah dalam pencapaian misi tersebut. Selain itu kepala sekolah menyusun target jangka panjang yang akan dilakukan. Seperti yang dipaparkan oleh kepala sekolah terhadap peneliti dalam wawancaranya. Bukti efektivitas penyusunan Visi dan Misi Sekolah ini ditunjukkan dengan tersedianya : undangan rapat penyusunan visi dan misi, daftar hadir, buku pedoman penyusunan visi dan misi serta dokumen visi dan misi. Selain itu perilaku kepala sekolah dalam memfasilitasi dan komunikasi cenderung bersifat sebagai fasilitator, berkolaboratif, partisipatif dan bijaksana kepada guru, siswa, alumni dan stakeholder. Apa yang dilakukan ibu kepala sekolah sebagai administrator sekolah mencoba menekan struktur gender itu sendiri dalam perbedaan perilaku kepemimpinan. Dibenarkan oleh peneliti sebelumnya bahwa kepala sekolah perempuan cenderung mengadopsi "maskulin" bersama dengan sifat "feminin" untuk menyesuaikan diri sehingga dengan mudah dapat menyatu bersama guru, wakil kepala sekolah, stakeholder dan siswa untuk pemasaran pendidikan (Reay \& Ball, 2000).

b. Efektivitas kepala sekolah dalam dalam memimpin dengan penuh tanggung jawab dan mampu menciptakan iklim sekolah yang kondusif

Temuan penelitian berkaitan kepemimpinan sekolah dam mengondisikan iklim sekolah yang kondusif sehubungan dengan pelaksanaan 8 standar proses pendidikan (mencakup standar isi, standar kompetensi lulusan, pendidik dan tenaga kependidikan, sarana dan prasarana, standar pengelolaan serta standar pembiayaan pendidikan) telah dipenuhi sehingga tercipta lingkungan sekolah yang kondusif serta dapat bertanggung jawab terhadap apa yang menjadi beban dan tanggung jawab kepala sekolah. Dengan gaya kepemimpinan yang tegas, disiplin, penuh kasih sayang, bertanggung jawab dan transparan serta dekat dengan warga sekolah (kolega guru, tenaga kependidikan , para siswa dan orang tua siswa) dalam mengelola sekolah yang dipimpinnya semua pekerjaan yang berat dan sulit dapat dipecahkan secara bersama-sama melalui suasana yang nyaman dan kekeluargaan, dan selanjutnya akan terjadi semangat kebersamaan dan menimbulkan rasa aman dalam berkarya.

c. Temuan hasil penelitian mengenai efektifitas kepala sekolah dalam memonitoring aktivitas guru serta hasil belajar siswa.

Temuan penelitian terkait dengan tugas kepala sekolah sebagai supervisi kepala sekolah melakukan memonitoring pengajaran dalam bentuk kunjungan kelas dan mengecek kelengkapan adminisfiatif dilakukan secara kekeluargaan demi terwujudnya kenyamanan dan keamanan bagi warga sekolah. Khusus supervisi perkunjungan kelas dilakukan secara langsung masuk ke kelas, mengamati guru yang sedang mengajar, sedangkan supervisi perkunjungan kelas 
tidak langsung dilakukan kepala sekolah di luar kelas. Hasil kunjungan dituangkan dalam suatu dokumen berupa laporan supervise, sehingga dari buku laporan ini kepala sekolah dapat mendeskripsikan kinerja guru dan kinerja kepala sekolah. Temuan penelitian bahwa gaya kepemimpinan kepala sekolah lebih partisipatif dan demokratis feminism, dengan sifat keibuan dan lemah lembut mencoba menggali keinginan guru dan tenaga pendidikan sebagai kolega sekolah untuk bersama-sama mewujudkan mutu pendidikan yang baik selaras dengan hasil riset peneliti sebelumnya bahwa perempuan lebih efektif dalam pengaturan atau perencanaan pendidikan dan layanan sosial, serta dalam posisi manajemen tingkat menengah yang mendukung keterampilan interpersonal (Alice H Eagly \& Carli, 2012). Penelitian yang lain juga menyebutkan bahwa gaya kepemimpinan yang berperspektif gender lebih efektif dalam perencanaan pendidikan walaupun kepala sekolah perempuan lebih banyak menggunakan waktu dalam layanan social (Fridell, Belcher, \& Messner, 2009).

Tanggung jawab utama kepala sekoah sehubungan dengan kesiswaaan dan memotivasi guru-guru untuk lebih bertanggung jawab melaksanakan tugas-tugas para guru dilakukan dengan pendekatan persona agar terjalin kekeluargaan dan tetap tertib administratif. Kepala sekolah cukup teliti membaca perkembangan hasil belajar siswa. Para guru dan wali kelas diminta memberi laporan terhadap perkembangan belajar siswa karena mereka yang dahulu mengumpulkan data tentang hasil belajar siswa. Para siswa juga dilibatkan secara aktif tidak hanya menyangkut kegiatan formal kurikuler tetapi juga melalui progam ekstra kurikuler berkaitan dengan prestasi ekstrakulikuler terus didorong dan dipantau oleh ibu kepala sekolah, antara lain nampak dari piala-piala yang diperoleh siswa pada berbagai perlombaan baik di tingkat kabupaten /kota seperti yang nampak pada ruang kepala sekolah piala-piala yang didapat pada mata pelajaran Pendidikan Kesehatan Jasmani , kesenian dan prestasi 02SN. Keberhasilan ibu kepala sekolah menjadikan stereotype yang dimiliki perempuan seperti perempuan lemah lembut, disiplin, lemah, perempuan tidak cocok jadi pemimpin dijadikan modal bagi ibu kepala sekolah dengan cara berkolaborasi dan demokratis dengan warga sekolah demi mewujudkan lembaga pendidikan yang bermutu. Selaras dengan hasil penelitian sebelumnya dikatakan bahwa kepala sekolah yang mengadopsi gaya kepemimpinan model transformasional dan demokratis maka gaya tersebut semakin berkorelasi dengan efektivitas. Perempuan dengan gaya kepemimpinan tranformasional dan demokratis lebih selaras dan efektif daripada kepemimpinan laki-laki (Alice H Eagly \& Carli, 2003).

d. Temuan hasil penelitian Efektifitas kepala sekolah dalam melibatkan orang tua dan masyarakat sekitar dalam kegiatan sekolah

Efektifitas kepala sekolah dalam melibatkan orang tua dan masyarakat sekitar dalam kegiatan sekolah, biasanya dilakukan di awal dan di akhir semester. Di awal semester biasanya para orang tua dikumpulkan terkait dengan pengenalan program sekolah. Kepala sekolah menginformasikan sistema penerimaan, proses pembelajaran sampai pada sistem penilaian agar para orang tua siswa juga ikut berperan dalam mendampingi putra/putrinya dalam menimba ilmu. Strategi yang digunakan kepala sekolah dengan pendekatan kekeluargaan, penuh tanggung jawab , transparan dan saling menghormati. Begitu pula di akhir semester, kepala sekolah melalui guru kelas menginformasikan 
hasil evaluasi belajar siswa dan program untuk meningkatkan mutu. Selain komponen warga sekolah guru dan siswa beserta staff pendukung lainnya keterlibatan dan dukungan orang tua dalam penyelenggaraan pendidikan memberikan andil yang besar bagi efektifitas suatu sekolah. Dalam hal hubungan dengan orang tua kepala sekolah merupakan mata rantai penting guna membuka saluran 2 arah secara harmonis antara sekolah dan sebaliknya.Untuk membangun komunikasi 2 arah tersebut kepada sekolah harus memiliki ketrampilan membaca harapan, nilai dari orang tua.

\section{SIMPULAN}

Penerapan model CIPP dalam analisis kepemimpinan Kepala Sekolah SMP Negeri 4 sendawar dikatakan efektif seperti diuraikan Duncan yang dikutip Richard M. Steers bahwa pencapaian efektivitas kepemimpinan kepala sekolah ditandai dengan keseluruhan upaya pencapaian sebagai proses yang panjang dan sistematis yang diawali dengan merumuskan visi dan misi. Sebagai dokumentasi sekolah visi misi sekolah SMPN 4 Sendawar terpampang di setiap ruang kelas, semua ruang sekolah SMPN 4 dan dituangkan dalam RPP serta diimplementasikan dalam proses belajar mengajar, rapat (guru, siswa, dan komite sekolah) Selain itu pencapaian prestasi yang diraih juga berkaitan dengan misi peningkatan prestasi baik akademik maupun non akademik.

Efektivitas kepala sekolah dalam memimpin dengan tanggung jawab berhasil menciptakan iklim sekolah dan budaya sekolah yang kondusif sehingga warga sekolah dapat menikmati suasana kerja, lingkungan belajar yang nyaman dan ramah anak. Efektivitas kepemimpinan kepala sekolah diikuti dengan keberhasilan pencapaian 8 stándar nasional pendidikan:

1. Pencapain Target Kurikulum (Standar Isi)

Mengenai teknis pelaksanaan standar isi sekolah belum sepenuhnya dapat melaksanakan kurikulum dengan pendekatan multistrategi dan multimedia sebagai media sumber belajar, namun sejauh ini yang telah dilaksanakan sudah cukup memadai.

2. Pencapain Target Standar Kompetensi Lulusan (SKL)

Kemampuan peserta didik berdasarkan Nilai SKHU/UASBN dan tes tertulis pada saat penerimaan siswa baru maupun nilai raport memiliki kemampuan akademik sedang, Pencapaian yang baik yakni pada saat tahun ajaran 2017/2018 SMP negeri 4 Sendawar meraih hasil Nilai UAN tertinggi se-Kutai Barat

3. Pencapaian Target Standar Proses

Standar proses yang sudah dilaksanakan yakni masing-masing guru mata pelajaran sudah membuat RPP dan sumber belajar berupa buku, LKS, serta menggunakan metode pembelajaran yang interaktif, inspiratif, kreatif dan menyenangkan. Meskipun secara keseluruhan hasil yang dicapai belum maksimal

4. Pencapaian Target Standar Pendidik dan Tenaga Kependidikan

Jika dilihat dari kualifikasi pendidikan $S 1$ yang telah sesuai dengan mata pelajaran yang diampu, sedangkan untuk jumlah tenaga kependidikan belum memenuhi kebutuhan sekolah, selain itu biasanya juga dilakukan dengan peningkatan kompetensi pendidik yakni dengan mengikuti pelatihan berbasis TIK, begitu pula dengan tenaga kependidikan. 
5. Pencapaian Target Standar Sarana dan Prasarana Pendidikan

Sarana dan prasarana yang ada di sekolah secara keseluruhan semuanya telah terpenuhi secara secara perlahan yang digunakan sebagai penunjang proses pembelajaran di sekolah.

6. Pencapaian Target Standar Pengelolaan

Mengenai standar proses pengelolaan di sekolah sejauh ini pelaksanaan visi dan misi serta program kerja jangka panjang dan jangka menengah telah berjalan sesuai dengan yang diharapkan, meskipun ada beberapa hambatan namun masih dapat teratasi, di setiap akhir pelaksanaan program kegiatan dilakukan monitoring dan evaluasi agar pelaksanaan program dapat terus berjalan sesuai dengan yang diharapkan.

7. Pencapaian Target Standar Pembiayaan

Pembiayaan yang ada di sekolah yakni biaya operasional SMP Negeri 4 Sendawar berasal dari dana rutin, BPPD, BOS-Pusat yang tersusun dan terprogram secara rinci dalam anggaran pendapatan belanja sekolah. Untuk meningkatkan mutu sekolah APBS setiap tahun mengalami peningkatan.

8. Pencapaian Target Standar Penilaian Pendidikan

Proses penilaian yang dilakukan yakni berdasarkan kesepakatan Guru dan sekolah melibatkan orang tua peserta didik untuk meningkatkan pencapaian hasil belajar siswa. Selanjutnya guru memberikan masukan-masukan terhadap hasil belajar siswa yang telah dicapai, sehingga orang tua dan sekolah mengetahui bagaimana proses penilaian yang dilakukan.

\section{DAFTAR PUSTAKA}

Acker, S. (1995). Carry on Caring: The Work of Women Teachers. British Journal of Sociology of Education, 16(1), 21-36.

Apriani, F. (2011). Pengaruh Kompetensi, Motivasi, dan Kepemimpinan terhadap Efektivitas Kerja. Bisnis \& Birokrasi Journal, 16(1).

Carli, L. L., \& Eagly, A. H. (1999). Gender Effects on Social Influence and Emergent Leadership.

Carli, L. L., \& Eagly, A. H. (2001). Gender, hierarchy, and leadership: An introduction. Journal of Social Issues, 57(4), 629-636.

Coder, L., \& Spiller, M. S. (2013). Leadership education and gender roles: Think manager, think"?". Academy of Educational Leadership Journal, 17(3), 21.

Djafri, N. (2017). Manajemen Kepemimpinan Kepala Sekolah:(Pengetahuan Manajemen, Efektivitas, Kemandirian Keunggulan Bersaing dan Kecerdasan Emosi). Deepublish.

Eagly, Alice H, \& Carli, L. L. (2003). Finding Gender Advantage and Disadvantage: Systematic Research Integration is The Solution. The Leadership Quarterly, 14(6), 851-859.

Eagly, Alice H, \& Carli, L. L. (2012). Women and The Labyrinth of Leadership. Contemporary Issues in Leadership, 147-162.

Eagly, Alice Hendrickson, Eagly, L. L. C. A. H., \& Carli, L. L. (2007). Through The Labyrinth: The Truth About How Women Become Leaders. Harvard Business Press.

Fridell, M., Belcher, R. N., \& Messner, P. E. (2009). Discriminate analysis gender public 
school principal servant leadership differences. Leadership \& Organization Development Journal.

Gibson, J. L., Ivancevich, J. M., \& Donnelly, J. H. (1996). Organisasi: Perilaku, Struktur dan Proses. In Bina Rupa Aksara. Jakarta.

Hoyt, C L, \& Simon, S. (2016). Gender and leadership. Leadership Theory and Practice, 397-426.

Hoyt, Crystal L, \& Burnette, J. L. (2013). Gender Bias in Leader Evaluations: Merging Implicit Theories and Role Congruity Perspectives. Personality and Social Psychology Bulletin, 39(10), 1306-1319.

Reay, D., \& Ball, S. J. (2000). Essentials of female management: women's ways of working in the education market place? Educational Management \& Administration, $28(2), 145-159$.

Stufflebeam, D. L. (2007). CIPP evaluation model checklist. Retrieved January, 8(2012), 717-733.

Sutanto, E. M., \& Stiawan, B. (2000). Peranan Gaya Kepemimpinan yang Efektif dalam Upaya Meningkatkan Semangat dan Kegairahan Kerja Karyawan di Toserba Sinar Mas Sidoarjo. Jurnal Manajemen dan Kewirausahaan, 2(2), 29-43.

Wibowo, I., Si, M., \& Saputra, W. (2017). Pengaruh Gaya Kepemimpinan Terhadap Kinerja Pegawai Melalui Disiplin Dan Motivasi Kerja Pegawai PPSU Kelurahan Duren Sawit Jakarta Timur. Jurnal Manajemen Bisnis Krisnadwipayana, 5(2).

Winardi, J., Nurkolis, N., \& Yuliejantiningsih, Y. (2017). Pengaruh Kepemimpinan Kepala Sekolah Dan Kompetensi Profesional Guru terhadap Sekolah Efektif pada SMP Negeri Rayon Patebon Kabupaten KendaL. Jurnal Manajemen Pendidikan $(J M P), 6(2)$.

Wirawan, D. (2013). Kepemimpinan: Teori, Psikologi, Perilaku Organisasi, Aplikasi dan Penelitian. Jakarta PT. Rajagrafindo Persada. 
Volume : 07

Nomor : 01

Bulan : Januari

Tahun : 2021

http://ejurnal.pps.ung.ac.id/index.php/AKSARA/index

14 AKSARA: Jurnal IImu Pendidikan Nonformal 